\title{
BCL5 Gene
}

National Cancer Institute

\section{Source}

National Cancer Institute. BCL5 Gene. NCI Thesaurus. Code C122817.

Human BCL5 gene is located in the vicinity of $17 q 22$ and is approximately $2 \mathrm{~kb}$ in length.

This phenotype-only gene has not been linked to a known protein product. This locus

may play a role in hematopoiesis. Chromosomal rearrangements involving this gene

locus may be associated with both aberrant expression of the MYC gene and leukemia. 